\title{
A Study of Factors Influenced Online Shopping Behavior in Malaysia: A Structural Approach
}

\author{
RUSNIFAEZAH MUSA, SELVAMALAR NASARATNAM, \\ KALAISELVEE RETHINAM, PARTEEBAN M. VARATHARAJOO, \\ ARUNAGIRI SHANMUGAM* \\ Faculty of Business and Management, AIMST University, \\ Bedong, Kedah, MALAYSIA
}

\begin{abstract}
Online shopping becomes a key tool as the business landscape is modifying. Thus, the behavior of consumer will change accordingly towards online shopping. This study aimed to determine factors influence the online shopping behavior in Malaysia. Six independent factors and one mediator were tested to the dependent variable, online shopping behavior: customer satisfaction, security, site design, convenience, delivery, product brand, perceived usefulness. The questionnaire was adopted in accordance with previous research. Data were collected using survey method. About 352 data were collected from 400 questionnaires distributed through convenience sampling to respondent who want to consume green product. The data was analyzed using statistical packages for the social sciences (SPSS) version 27 and SMART PLS version 3.3.7. Findings postulates delivery, customer satisfaction, and perceived usefulness were significant towards online shopping behavior in Malaysia. Meanwhile, convenience, delivery, and site design were found significant with customer satisfaction. In other findings, customer satisfaction also mediates the relationship between convenience, delivery, design with online shopping behavior. The R2 (40\%) of the study indicates the model have a moderate fit of model. In order to build engagement of the audience in social media, the business or marketing manager needs to share valuable and informative content in social media. The social media marketers also need to post high-quality, unique content to drive the reach of the post or videos of their business. This will create a strong relationship between the business and customers through social media platform.
\end{abstract}

Keywords: - Online shopping behavior, customer satisfaction, convenience, delivery, site design, structural model.

Received: May 8, 2021. Revised: December 14, 2021. Accepted: January 23, 2022. Published: January 25, 2022.

\section{Introduction}

Electronic commerce has exploded in recent years as a result of extensive technical advancement. According to a survey from e-Marketer, both the number of online shoppers and the amount of money spent on the internet are continually increasing [1]. Furthermore, many emerging countries, such as Malaysia, rely on it heavily. People are becoming increasingly connected to social media platforms, bridging the geographical divide that formerly separated people [2]. According to [3], they define online purchasing as an individual's activities that are motivated by the desire to shop online. Social media is one of the most popular sites for online buying. Web 2.0's conceptual and technical basis define social media as an online application that allows users to communicate with one another [4]. Consumers' online shopping behaviour is influenced by their use of social media.

In addition to that, consumers are increasingly using the internet and spending more time searching for information, which has a significant impact on their purchasing decisions. Accordingly, the impact of social media platforms on markets, corporations, and individuals is significant. As a result, organizations use platforms like Instagram, Facebook, and even WhatsApp to build social media profiles for their products and services in order to reach out to their target consumers globally. Moreover, with social media marketing, the nature of relationships between businesses and consumers is interactive and direct [5]. The current pandemic situation, social media was the only method to get the word out about these new products and services. Because many countries are on lockdown and most consumers are afraid to travel to a real store, the 
next best choice is online shopping, which includes purchases made through social media.

In 2020, the number of social media users has risen to 26 million, up from 19 million in 2019, and this statistic only applies to Malaysia. The number of people using social media is growing every day; everyone, young and old, has at least one account. In fact, more than $95 \%$ of social media platforms for people aged 18 to 34 are targeted towards this demographic. The goal of this study was to figure out what factors influence Malaysians' internet buying habits. Customer satisfaction, security, site design, ease, delivery, product brand, and perceived usefulness were all assessed in relation to the dependent variable, online buying behaviour.

\section{Literature Review}

\subsection{A Review of Current Trend of Online Shopping Behavior}

The increased use of the internet around the world has resulted in a new type of consumer behaviour, in which customers' focus has switched to online shopping. Consumer behaviour is shifting away from traditional ways as consumer faith in technology and online payment industries grows [6]. According to the [7] postulates an estimated 1.8 billion individuals throughout the world now shop online and there are over 3 billion internet users worldwide, signifying a 577 percent rise in growth since the year 2000. This development suggests that online shopping has a lot of potential and benefits for people and businesses all over the world. Due to the current COVID-19 pandemic, online shopping has become more of a need than an option for purchasing goods. Lockdown situations have forced consumers who are not familiar with online shopping to move towards this behavior [8]. This paper aimed to study the influenced factors of consumer shopping online in Malaysia and the mediation role of customer satisfaction in relationship of intend factors (security, site design, convenience, delivery, perceived usefulness, and product brand.

\subsection{Online Shopping Behavior}

The term "online shopping behaviour" refers to the act of purchasing things and services through the internet [9]. The Internet, in particular, is critical in our day. Initially, the internet was used just for information retrieval [10], but it is currently utilised for a variety of reasons, including commerce and social networking. Customers utilise the internet to purchase things because it is more convenient for them, and the word convenient incorporates characteristics such as time savings, information accessibility, opening hours, ease of use, website navigation, reduced shopping stress, lower prices, and shopping enjoyment [11], [12]. In another research, [13] examined offline and internet purchasing and found that online shopping is more convenient and time-efficient than offline shopping. Apart from that, internet shopping provides clients with more product and service information, enabling them to compare pricing and the quality of products offered by different vendors. Numerous physical and intangible factors, such as social media, brand, time restrictions, and even consumer perceptions, all impact online buying behaviour. All of these factors have had a significant influence on how customers purchase online.

\subsection{Customer Satisfaction towards Online Shopping}

Customer satisfaction is defined as the summary of psychological state resulting when the emotional surrounding disconfirmed expectations that is coupled with prior feelings about the customer experience [14]. Customer satisfaction is when products and services meet the expectation of the consumers which leads to repetitive purchases. Customer satisfaction is a central component of marketing interest [15] and it is regarded as the primary marketing goal. It is also defined as the overall customer attitude towards a service provider. Which are the emotional reactions to what the customer received and what they expect to fulfill their need, goal or desire [16][17]. Online customer satisfaction is defined as the customer's contentment which is related to his or her previous purchasing experience with a given online shopping platform firm [18]. According to [19] customers' online shopping is influenced by benefit perception, which is referred as the sum of online shopping advantages or satisfactions that meet an individual's needs or wants.

\subsection{Security}

According to [20] security refers to customer's perception on the protection of the information that are shared during their online experience to access the website. Security can be described as the extent to which shoppers consider that their payment online is free from unauthorized access, use, change and destruction [21]. The concern for the security can be grouped into two categories which are financial and non-financial [22]. Both the categories are essentially important consideration for 
consumers before they decide to they engage into any online shopping activity. Security is the trust that consumers have that the transactions and financial information related to bank information is safe. Security is a vital factor to influence customer's online shopping experience.

Based on the previous studies showed that security will provide the trust to consumers to continue with their online shopping experience. Study by [23] stressed that security is an important factor among consumers to make decision on their purchase. As mentioned earlier, it is very essential for users to feel comfortable as they are aware that the company that they are engaged in purchase transactions will process vast data and information related to the consumers especially the concern on their personal information. According to [24], security has great impact to provide the trust and confidence among consumers in using online shopping platform. And most importantly trust that on security factor encourage customers to engage in the online shopping. Meanwhile, [25] found that behavioural intention was influenced by security. And to justify to this claim, findings of [26] highlighted that security is the main reason that customers have fear and reluctant to accept online banking. So this justifies that security factor must be ensured by website owners and trade organizations to convince customers on their online transactions [27]. The trust will definitely provide confidence to the customers in their online shopping behaviour.

\subsection{Site Design}

According to [28] the site design refers to customer experience accessing to the retail website and the features includes information quality, website aesthetics, purchase process, website convenience, product selection, price offerings, website personalization, and system availability. And researcher [29] have also emphasized that an efficient website should contain the three categories as information-oriented, transaction-oriented, and customer-oriented.

The site design is desirable to provide the aesthetics elements of a design to ensure that the website is usable. Apart from that, the site design should also reflect the strong brand image and eventually should attract the online customers to visit the website [30]. Customers assess their experience of using a website to perceive their general experience in online shopping. In aligned to the same findings, [31] found a significance relationship between online shopping activities with the website features. According to study by [32] found insignificant relationship between site design and online shopping behaviour. Online consumer prefers those online sellers to create their online store with a superb web atmospherics, consistence eye catching graphics and has a very interested website design and layout [33].

The site design could also allow the customers to express their feelings whether positive or negative feelings with the website. Besides, this will also motivate the consumer to revisit the website. According to the empirical findings by[34] revealed that site design is linked with the perceptions of online service quality among customers. These studies as discussed have shown that site design is an important factor for customers to make decision to engage and stay engaged with online shopping using the website as it is the platform to view and shop the products provided in the online store.

\subsection{Convenience}

Convenience refers to the minimized time and effort taken to purchase products and services [35]. Based on recent studies by [13], online hopping provides the ease as it provides consumers their own time to experience the online shopping even when they are busy. Consumers may continue with their purchase at their own comfort. And especially with the impact of pandemic Covid-19, consumers are opting to online shopping as it is more convenient especially with to the social distancing to take into consideration. Study conducted by [36] revealed that the findings on young Malaysians shows that online shopping is a preference due to the convenience that it provides. In addition to that, findings by [6] that the most crucial factor that influences online shopping is convenience. Therefore, convenience is one of the aspects that retail websites may offer to add value to customers [37]. More recent studies, however, showed that convenience has a direct effect on purchasing trends [38][39]. The discussion shows that the consumers are willing to engage in the online shopping behavior when they are convinced that the online activity is convenient and able to safe their time and comfort. And at recent times, with the pandemic that cause panic and worry among consumers, online shopping ease and provide the convenience to them to do shopping without any face to face or physical contact that may expose them to risk of the pandemic.

\subsection{Delivery}

According to surveys, the value placed on delivery is increasing in lockstep with the expansion of 
online shopping [40]. According to studies, delivery is a critical component to consider when determining a customer's level of satisfaction with an online purchasing platform [41][42]. According to specific study, customers place a premium on delivery as a critical component since they have already paid for the service [43]. According to another study, customers are equally as concerned about delivery times as they are about delivery prices [44]. Delivery performance, usually referred to as on-time delivery, has a positive effect on customer satisfaction [45]. According to earlier research [44], customer dissatisfaction is induced by product delivery delays. Therefore, on-time delivery is seen as a significant component in determining the success of online shopping in a particular area [40][42][44][45].

\subsection{Product Brand}

A brand is a name, term, symbol, design, or mix of these things that is used to identify a seller's or a group of sellers' goods and services and distinguish them from those of competitors [46]. According to prior study, a brand is created by the consumers' perceptions and experiences, thus a sensible and conscious shopper will only purchase brands that he is familiar with and find appealing [47]. Even if customers wish to buy a certain product, brand recognition will be the most essential and influencing aspect in their selection. According to researchers, it's critical to examine how consumers create relationships or interact with brands, as well as their ability to form brand communities in their own lives [48]. According to [49], brand awareness arose from a large collection of disparate pieces, which was dependent on the extension of marketing messages to other fields. [50] described a type of loyal consumer that makes purchases regardless of price, and who expresses their devotion by making favorable recommendations for businesses and even investing money in the brand, demonstrating their complete trust in the company.

\subsection{Perceived Usefulness}

[51] defined perceived usefulness in the TAM model as the extent to which an individual believes that applying an innovation increases job performance. This definition originates from the word useful, which means the ability to be used advantageously. Perceived usefulness refers to the advantage that someone derives from technology usage. The desire to utilise technology has an effect on the users' competence, and the intention is impacted by perceived utility and simplicity of use [52]. In different findings, [53] revealed that perceived risk and perceived utility are influencing variables in Bangladesh's m-commerce adoption. Similarly, [54] said that perceived utility and emotion played a crucial role in explaining both mcommerce use and desire to use through perceived value. In Indonesia, there is also an issue with a slow internet network [52]. Similarly, [55] said that perceived utility had a direct effect on mobile banking adoption in Thailand.

\section{Methodology}

Figure 1 below depicts the conceptual framework of this study based on the discussion of variables in literature review section.

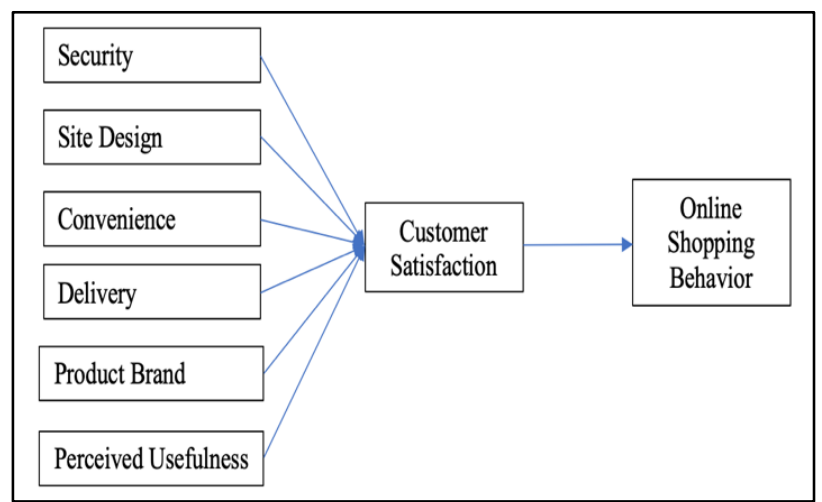

Fig. 1: Research Framework of Online Shopping Behavior

This study used a quantitative research design. The study's target audience was consumers who buy online via websites such as shoppee, facebook, Instagram, and Lazada. Responses from consumers were gathered through an online survey. To collect prospective responders, an intercept technique was utilised on Facebook pages, Twitter, Instagram, and any online shopping website platform. A total of 352 valid surveys from targeted consumers were gathered. From 352, about nine responded were discarded due to outliers. The questionnaire's measurement item was modified from prior research. A five-point Likert scale was used, with a score of "1" representing "strongly disagree" and a score of "5" representing "strongly agree." A total of 343 were carry for further analysis. Smart-PLS version 3.0 was used to analyse the measurement and structural model for this study.

\section{Findings}

\subsection{Demographic Profile}


WSEAS TRANSACTIONS on BUSINESS and ECONOMICS DOI: 10.37394/23207.2022.19.48

Respondent's demographic profile described the background of the respondent ranging from their gender, age, income, and education. The difference in gender shows a big difference as the females prefer to do online shopping more than male. The female respondent is at 62.7 percent compared to male respondent at 37.3 percent. While analyzing the respondent demographic profile, age of the respondent became a crucial indicator to show that most respondents at the age of 21-25 years prefer to shop online. Hence, the finding shows that respondents at the age of 21-25 years are the highest to do online shopping at 66.7 percent.

Respondents also were asked about their monthly income. 73.3 percent of respondents have monthly income less than 2,000. From 343 respondents, there was only one respondent at 0.29 percent having monthly income more than 11,000 . On the other hand, 22.7 percent of respondents had monthly income at 2001-5000 and there were only five respondents at 3.7 percent who had 5000110,000 .Additionally, in term of level of education, most of the respondents are bachelor's degree holders at 55.3 percent followed by High school and diploma holders at 14.7 percent. Only two respondents were master's degree holders at 1.3 percent while Foundation, STPM, and Pre-diploma holders at 13.33 percent.

\subsection{Measurement Model}

Table 1 shows the measurement model of Intention to consume green product which explained the factor loadings and reliability of the constructs. [56] explained that the reliability of a single observed variable describes the variance of an individual observed which was compared to an unobserved variable by evaluating the standardised outer loadings of the observed variables. Meanwhile, the observed variables with an outer loading of 0.7 or greater are agreed to be acceptable [57], while the outer loading with a value less than 0.7 should be discarded [58]. For this study, the cut-off value accepted for the outer loading is 0.7 . There were only 1 item deleted (CONV2) as it has loading below

[57].

Table 1. Reliability and Validity of Constructs $(n=343)$

\begin{tabular}{|c|c|c|c|c|}
\hline & & & AVE & CR \\
\hline \multirow[t]{5}{*}{ Online Shopping Behaviour (OSB) } & OSB 1 & 0.913 & 0.793 & 0.950 \\
\hline & OSB 2 & 0.821 & & \\
\hline & OSB 3 & 0.936 & & \\
\hline & OSB 4 & 0.930 & & \\
\hline & OSB 5 & 0.847 & & \\
\hline \multirow[t]{4}{*}{ Security (SEC) } & SEC 1 & 0.910 & 0.827 & 0.950 \\
\hline & SEC 2 & 0.911 & & \\
\hline & SEC 3 & 0.922 & & \\
\hline & SEC 4 & 0.895 & & \\
\hline \multirow[t]{4}{*}{ Site Design (SD) } & SD 1 & 0.880 & 0.793 & 0.939 \\
\hline & SD 2 & 0.888 & & \\
\hline & SD 3 & 0.894 & & \\
\hline & SD 4 & 0.899 & & \\
\hline \multirow[t]{3}{*}{ Convenience (CON) } & $\mathrm{CON} 1$ & 0.701 & 0.700 & 0.873 \\
\hline & $\mathrm{CON} 3$ & 0.910 & & \\
\hline & $\mathrm{CON} 4$ & 0.888 & & \\
\hline \multirow[t]{4}{*}{ Delivery (DEL) } & DEL 1 & 0.901 & 0.833 & 0.952 \\
\hline & DEL 2 & 0.923 & & \\
\hline & DEL 3 & 0.903 & & \\
\hline & DEL 4 & 0.923 & & \\
\hline \multirow[t]{5}{*}{ Product Brand (PB) } & PB 1 & 0.874 & 0.769 & 0.943 \\
\hline & PB 2 & 0.817 & & \\
\hline & PB 3 & 0.921 & & \\
\hline & PB 4 & 0.814 & & \\
\hline & PB 5 & 0.855 & & \\
\hline
\end{tabular}




\begin{tabular}{lllll}
\hline Perceived Usefulness (PU) & PU 1 & 0.931 & 0.657 & 0.905 \\
& PU 2 & 0.935 & & \\
& PU 3 & 0.950 & & \\
PU 4 & 0.926 & & \\
& PU 5 & 0.895 & 0.675 \\
& SI 1 & 0.820 & 0.912 & \\
& SI 2 & 0.776 & & \\
SI 3 & 0.853 & & \\
& SI 4 & 0.819 & & \\
& SI 5 & 0.838 & & \\
\hline
\end{tabular}

According to [59], the Average Variance Extracted (AVE) should be higher than 0.5. However, even if the AVE is less than 0.5 ( 0.4 is still acceptable), but the composite reliability is higher than 0.6 , the convergent validity of the construct is still adequate [59]. As shown in Table 1, the AVE for all the variables in this study exceeded 0.5 and was validated for the structural analysis.

\begin{tabular}{ccccccccc}
\multicolumn{6}{c}{ Table 2 2. Discriminant Validity of Latent Variables } \\
\hline & 1 & 2 & 3 & 4 & 5 & 6 & 7 & 8 \\
\hline 1 & 0.836 & & & & & & & \\
2 & 0.070 & 0.913 & & & & & & \\
3 & 0.180 & 0.531 & 0.822 & & & & & \\
4 & 0.110 & 0.522 & 0.580 & 0.890 & & & & \\
5 & 0.280 & 0.072 & 0.060 & -0.034 & 0.928 & & & \\
6 & 0.437 & 0.077 & 0.124 & 0.097 & 0.339 & 0.877 & & \\
7 & 0.291 & 0.097 & 0.142 & 0.064 & 0.227 & 0.557 & 0.909 & \\
8 & 0.124 & 0.455 & 0.783 & 0.469 & 0.058 & 0.065 & 0.117 & 0.890 \\
\hline
\end{tabular}

Note: 1: convenience, 2: Delivery, 3: Customer satisfaction, 4: Online shopping behavior, 5: Perceived Usefulness, 6: Product brand, 7: Security, 8: Site design.

**Bold diagonal elements are the square root of AVE (Average Variance Extracted) which should exceed the off- diagonal inter-construct correlations for adequate discriminant validity.

The construct reliability (CR) for all the variables has a value above 0.85 . The discriminant validity of the latent variables in this study as shown in Table 2 illustrates all the bold diagonal elements that exceed the off- diagonal inter-construct correlations which indicate attitude (ATT) is 0.792, environmental concern (EC) is 0.841, environmental knowledge (EK) is 0.881, Health consciousness (HC) is 0.811 , Intention to consume green product (GPI) is 0.846 , perceived price (PP) is 0.851 , perceived value and quality (PVQ) is 0.932 and social influence is 0.913 . Hence, the value of all indicators loaded on their own construct is higher than on any other which is sufficient.

\subsection{Structural Model}

A structural model, through the bootstrapping analysis, was constructed (Streukens \& Werelds, 2016). A total of 5000 subsamples through bootstrapping were collected as per the results illustrated in Figure 2.

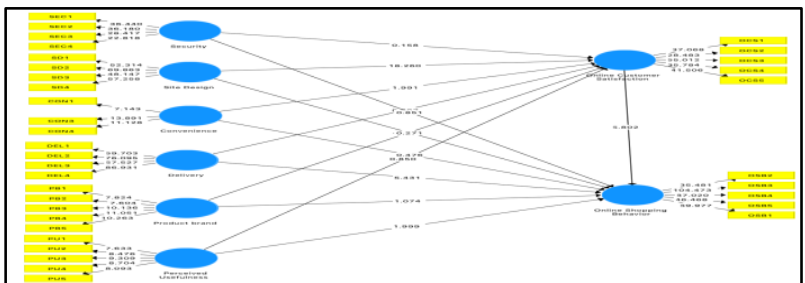

Fig. 2: Structural Model for Online Shopping Behavior.

Table 3 illustrates the findings of the direct hypotheses of this study. Of the 7 hypotheses, only 3 hypotheses were accepted.

Table 3. Direct Hypotheses Result of Structural Model 


\begin{tabular}{lccc}
\hline & Beta & T Values & P Values \\
\hline H1: Security $>>$ Online Shopping Behavior & -0.05 & 0.85 & 0.40 \\
H2: Site Design $>>$ Online Shopping Behavior & 0.02 & 0.27 & 0.79 \\
H3: Convenience $>$ Online Shopping Behavior & 0.02 & 0.48 & 0.63 \\
H4: Delivery $>$ Online Shopping Behavior & 0.31 & 5.43 & 0.00 \\
H5: Product brand $>>$ Online Shopping Behavior & 0.08 & 1.07 & 0.28 \\
H6: Perceived Usefulness $>>$ Online Shopping Behavior & -0.10 & 2.00 & 0.05 \\
H7: Online Customer Satifaction $>>$ Online Shopping & 0.40 & 5.80 & 0.00 \\
Behavior & & & \\
\hline
\end{tabular}

Delivery was found to be positively significant with online shopping behavior $(\beta=0.31, \mathrm{t}=5.43, \mathrm{p}<$ 0.01 ). Customer satisfaction also was found to be positively significant with online shopping behavior $(\beta=0.40, t=5.80, p<0.01)$. In contrast, perceived usefulness was found to be negatively significant with online shopping behavior $(\beta=-0.10$, $\mathrm{t}=2.000, \mathrm{p}<0.05)$ and Findings also shown that security do not influence online shopping behavior $(\beta=-0.05, \mathrm{t}=0.85, \mathrm{p}>0.01)$. Site design also was found to be not significant with online shopping behavior $(\beta=0.02, t=0.27, p>0.01)$, and covenience and product brand was found to be not significant with online shopping behavior $(\beta=0.02$, $\mathrm{t}=0.48, \mathrm{p}>0.01)(\beta=0.08, \mathrm{t}=1.07), \mathrm{p}>0.01)$ respectively. Hence, hypotheses $\mathrm{H} 4, \mathrm{H} 6$, and $\mathrm{H} 7$ were accepted whereas hypotheses $\mathrm{H} 1, \mathrm{H} 2, \mathrm{H} 3$, and H5 were rejected.

Table 4. Indirect Hypotheses Result of Structural Model

\begin{tabular}{|c|c|c|c|}
\hline & Beta & $\begin{array}{c}\mathrm{T} \\
\text { Values }\end{array}$ & $\begin{array}{c}\mathrm{P} \\
\text { Values }\end{array}$ \\
\hline H8: Convenience $\quad->\quad$ Online Customer & 0.029 & 1.971 & 0.049 \\
\hline $\begin{array}{l}\text { Satisfaction } \quad \text {-> Online Shopping Behavior } \\
\text { H9: Delivery -> Online Customer Satisfaction } \\
\text {-> Online Shopping Behavior }\end{array}$ & 0.088 & 4.006 & 0.000 \\
\hline $\begin{array}{l}\text { H10: Perceived Usefulness }->\text { Online Customer } \\
\text { Satisfaction }->\text { Online Shopping Behavior }\end{array}$ & -0.011 & 0.848 & 0.397 \\
\hline $\begin{array}{l}\text { H11: Product brand }->\text { Online Customer } \\
\text { Satisfaction }->\text { Online Shopping Behavior }\end{array}$ & 0.016 & 0.989 & 0.323 \\
\hline $\begin{array}{l}\text { H12: Security -> Online Customer Satisfaction } \\
->\text { Online Shopping Behavior }\end{array}$ & 0.002 & 0.158 & 0.875 \\
\hline $\begin{array}{l}\text { H13: Site Design }->\text { Online Customer } \\
\text { Satisfaction }->\text { Online Shopping Behavior }\end{array}$ & 0.272 & 5.482 & 0.000 \\
\hline
\end{tabular}

In examining the mediation effect, findings postulate that online customer satisfaction only mediates relationship between convenience, delivery and site design and online shopping behavior. Online customer satisfaction mediates the relationship between convenience and online shopping behavior $(\beta=0.029, \mathrm{t}=1.971, \mathrm{p}<0.05)$. Meanwhile online customer satisfaction mediates the relationship between delivery and online shopping behavior $(\beta=0.088, t=4.006, p<0.01)$ and mediates the relationship between site design and online shopping behavior $(\beta=0.272, \mathrm{t}=5.482$, $\mathrm{p}<0.01)$. Hence, hypotheses H8, H9, and H13 were accepted whereas hypotheses H10, H11, and H12 were rejected.

\section{Discussion and Conclusion}

The research sought to ascertain the difficulties encountered by customers while making an online purchase. The findings indicated that most respondents had both good and bad experiences purchasing online. There were several concerns or difficulties that consumers encountered while utilising an e-commerce platform. Consumers were encouraged to purchase from online sites by six factors: security while conducting transactions online, convenience of online shopping, engaging and informative web site design, product brand, and perceived utility of utilising a website to shop online. The findings may help e-tailers plan future tactics for meeting client wants and fostering customer loyalty.

According to the research, delivery was shown to be associated with online purchase behaviour [40][42][44][45]. This conclusion is consistent with recent research in which customers predicted a shorter delivery time when their purchase value was high; the presence of "want" and "should" goods in the online shopping cart indicated the existence of "want" products and "should" items [60]. Additionally, data indicate that buyers want expedited delivery not because of the costs but because of the product's worth. It does away with the notion of delivery prices being proportional to delivery speed as the basics of delivery service. Although in today's commercial environment, there are delivery courier firms that promise same-day delivery for a premium charge. On-time delivery is sometimes referred to as delivery performance, and it contributes positively to consumer e-satisfaction [44][45]. According to [61], there is a high correlation between reputation and satisfaction, which is also associated with consumer loyalty. If an online merchant has established his or her brand name or image, the client is more likely to favour that store over a new entry.

Online merchants may use a variety of techniques to convince individuals who are hesitant to purchase online, including identifying negative parts of consumers' concerns in order to convert the non-online shopper or irregular online consumer into a regular client. An online merchant must pay close attention to the product's quality, variety, design, and brand. To begin, the shop must improve product quality in order to earn the consumer's 
confidence. They may do this by providing comprehensive seller information and history, which will ideally increase customer confidence in that seller. Additionally, they may use marketing methods such as a user-friendly and secure website that enhances the purchasing experience of consumers, as well as an easy-to-use product search and navigation system on the website. Additionally, comprehensive product and service information, such as feature and use details, item descriptions and measurements, may assist consumers in determining which goods to buy. Customers are wary about revealing their financial information on any website [23][24].

Customers can trust any website based on its privacy policy, and merchants may offer customers with a clear security policy, privacy policy, and secure transaction server to alleviate any anxiety associated with online financial transactions [62]. Additionally, shoppers not only purchase basic things from online retailers, but also pay attention to items of a higher quality. As a result, if vendors can offer prompt and required help, as well as respond to all client inquiries within a 24-hour service window, consumers may find it more convenient to purchase from such websites [63]. Sellers must verify that their goods and services are internet compatible. Retailers may influence customers by using risk mitigation methods such as simple return and exchange policies. Although most vendors presently provide a plethora of incentives in the shape of discounts, gifts, and cashbacks, many of them are tailored to the demands of e-retailers rather than consumers. Additionally, trust must be established in the customer's thinking, which may be accomplished by the modification of privacy and security regulations. By using these tactics, marketers may pique consumers' interest in online buying.

\section{References:}

[1] Wu, W. Y., Ke, C. C., and Nguyen, P. T., Online shopping behavior in electronic commerce: An integrative model from utilitarian and hedonic perspectives. International Journal of Entrepreneurship, 2018, Vol. 22, No. 3, pp.116.

[2] Piatak J, Dietz N, and McKeever B., Bridging or deepening the digital divide: Influence of household internet access on formal and informal volunteering. Nonprofit and Voluntary
Sector Quarterly. 2019 Apr;48(2_suppl):123S$50 \mathrm{~S}$.

[3] Bhattacharya, Arijit, Manjari Srivastava, and Sanjeev Verma, Customer experience in online shopping: a structural modeling approach, Journal of Global Marketing, 2019, Vol.32, no. 1, pp.3-16.

[4] Kaplan, Andreas, and Michael Haenlein, Siri, Siri, in my hand: Who's the fairest in the land? On the interpretations, illustrations, and implications of artificial intelligence, Business Horizons, 2019, Vol. 62, no. 1, pp.15-25.

[5] Ibrahim, Blend, Social Media Marketing Activities and Brand Loyalty: A Meta-Analysis Examination, Journal of Promotion Management, 2021, pp. 1-31.

[6] Naseri, Roszi Naszariah Nasni. "What is a Population in Online Shopping Research? A perspective from Malaysia." Turkish Journal of Computer and Mathematics Education (TURCOMAT) 12, no. 4 (2021): 654-658.

[7] Internet World Statistics, 2020. Internet user's distribution in the world. Internet World Statistics. [online] Available at: www.internetworldstats.com

[8] Gopinath, Vidya. "Consumer behavior trends during COVID-19 pandemic." Int J Sci Dev Res, 2020, Vol. 5, pp. 310-3.

[9] Rehman, Shafique Ur, Anam Bhatti, Rapiah Mohamed, and Hazeline Ayoup. "The moderating role of trust and commitment between consumer purchase intention and online shopping behavior in the context of Pakistan." Journal of Global Entrepreneurship Research 9, no. 1 (2019): 1-25.

[10] Voramontri, D. and Klieb, L., 2019. Impact of social media on consumer behaviour. International Journal of Information and Decision Sciences, 11(3), pp.209-233.

[11] Melović, Boban, Damir Šehović, Vesna Karadžić, Marina Dabić, and Dragana Ćirović. "Determinants of Millennials' behavior in online shopping-Implications on consumers' satisfaction and e-business development." Technology in society 65 (2021): 101561.

[12] Setiawati, Ni Putu Ari, Denok Sunarsi, Syaechurodji Nurjaya, Abdul Manan, Ahmad Nurhadi, Heri Erlangga, Denny Aditya Dwiwarman et al. "Effect of Technology Acceptance Factors, Website Service Quality and Specific Holdup Cost on Customer Loyalty: A Study in Marketing Departement of Packaging Industry." Annals of the Romanian Society for Cell Biology (2021): 12685-12697. 
[13] Aryani, Dwi Nita, Rajesh Kumar Nair, Dana Xing Yue Hoo, Daisy Kee Mui Hung, Deborah Hong $\mathrm{Ru}$ Lim, Wei Ping Chew, and Amey Desai. "A Study on Consumer Behaviour: Transition from Traditional Shopping to Online Shopping During the COVID-19 Pandemic." International Journal of Applied Business and International Management (IJABIM) 6, no. 2 (2021): 81-95.

[14] Zamry, Ain Damia, and Syafiqah Md Nayan. "What Is the Relationship Between Trust and Customer Satisfaction?." Journal of undergraduate social science and technology 2 , no. 2 (2020).

[15] Mofokeng, T.E., 2021. The impact of online shopping attributes on customer satisfaction and loyalty: Moderating effects of e-commerce experience. Cogent Business \& Management, 8(1), p.1968206.

[16] Davras, Özgür, and Meltem Caber. "Analysis of hotel services by their symmetric and asymmetric effects on overall customer satisfaction: A comparison of market segments." International Journal of Hospitality Management 81 (2019): 83-93.

[17] Kim, Woo-Hyuk, Jeong-Lan Cho, and KyungSook Kim. "The relationships of wine promotion, customer satisfaction, and behavioral intention: The moderating roles of customers' gender and age." Journal of Hospitality and Tourism Management 39 (2019): 212-218.

[18] Al-dweeri, Rami Mohammad, Zaid Mohammad Obeidat, Mohammad Ahmad Al-dwiry, Muhammad Turki Alshurideh, and Alaa Mohammad Alhorani. "The impact of e-service quality and e-loyalty on online shopping: moderating effect of e-satisfaction and etrust." International Journal of Marketing Studies 9, no. 2 (2017): 92-103.

[19] Bhatti, Anam, and Shafique Ur Rehman. "Perceived benefits and perceived risks effect on online shopping behavior with the mediating role of consumer purchase intention in Pakistan." International Journal of Management Studies 26, no. 1 (2020): 33-54.

[20] Chiu, Chao- Min, Chen- Chi Chang, Hsiang- Lan Cheng, and Yu- Hui Fang. "Determinants of customer repurchase intention in online shopping." Online information review (2009).

[21] Chiemeke, S. C., and A. E. Evwiekpaefe. "A conceptual framework of a modified unified theory of acceptance and use of technology (UTAUT) Model with Nigerian factors in E- commerce adoption." Educational Research 2, no. 12 (2011): 1719-1726.

[22] Chiang, Hsiu-Sen, and Ching-Chiang Chen. "A study of interactive qualitative at online shopping behavior." Wseas Transactions on Information Science and Applications 7 (2010): 166-176.

[23] Hossain, Afzal, Md Abdullah Al Jamil, and Md Masihur Rahman. "Exploring the Key Factors Influencing Consumersâ€ $€^{\mathrm{TM}}$ Intention, Satisfaction and Loyalty towards Online Purchase in Bangladesh." International Journal of Economics and Financial Research 4, no. 7 (2018): 214-225.

[24] Abid, Muhammad Mim Farisal, and Dinalestari Purbawati. "Pengaruh E-Security dan E-Service Quality Terhadap E-Repurchase Intention Dengan E-Satisfaction Sebagai Variabel Intervening Pada Konsumen E-Commerce Lazada di Fisip Undip." Jurnal Ilmu Administrasi Bisnis 9, no. 1 (2020): 93-100.

[25] Merhi, Mohamed, Kate Hone, and Ali Tarhini. "A cross-cultural study of the intention to use mobile banking between Lebanese and British consumers: Extending UTAUT2 with security, privacy and trust." Technology in Society 59 (2019): 101151.

[26] Tarhini, A., C. Mgbemena, M. S. A. Trab, and R. Masa'Deh. "User adoption of online banking in Nigeria: A qualitative study." The Journal of Internet Banking and Commerce 20, no. 3 (2015).

[27] Kumar, Dr, and Ujwala Dange. "A study of factors affecting online buying behavior: A conceptual model." Ujwala, A Study of Factors Affecting Online Buying Behavior: A Conceptual Model (August 25, 2012) (2012).

[28] Rita, Paulo, Tiago Oliveira, and Almira Farisa. "The impact of e-service quality and customer satisfaction on customer behavior in online shopping." Heliyon 5, no. 10 (2019): e02690.

[29] Hung, Chia-Liang. "Online positioning through website service quality: A case of star-rated hotels in Taiwan." Journal of Hospitality and tourism management 31 (2017): 181-188.

[30] Díaz, Estrella, and Christina Koutra. "Evaluation of the persuasive features of hotel chains websites: A latent class segmentation analysis." International Journal of hospitality management 34 (2013): 338-347.

[31] Sulaiman, Y., Jamil, N.A.M., Othman, A.R., \& Musa, R. (2020). The influence of green marketing, syariah compliance, customer's environmental awareness and customer's satisfaction towards muslim consumer 
purchasing behaviour in Kedah. WSEAS Transactions on Business and Economics, 17, 195-204

[32] Khan, Asma, and Asif Ali Syed. "Determinants of online consumer behaviour towards e-tailing in India." International Journal of Enterprise Network Management 9, no. 3-4 (2018): 455480.

[33] Yartey Ajayi, Lady, Oladokun Omojola, L. O. Amodu, and Naomi Ndubueze. "Personal Data Collection and Usage for Mobile Marketing Customer Awareness and Perception." WSEAS Transactions on Business and Economics 18 (2020).

[34] Giao, Ha Nam Khanh, Bui Nhat Vuong, Dao Duy Tung, and Tran Nhu Quan. "A Model of Factors Influencing Behavioral Intention to Use Internet Banking and The Moderating Role of Anxiety: Evidence from Vietnam." WSEAS Transactions on Business and Economics 17 (2020): 551-561.

[35] Jiang, Ling Alice, Zhilin Yang, and Minjoon Jun. "Measuring consumer perceptions of online shopping convenience." Journal of Service management (2013).

[36] Vasudevan, Puveandharan, and Lawrence Arokiasamy. "Online Shopping Among Young Generation In Malaysia." Electronic Journal of Business and Management6, no. 1 (2021): 3138.

[37] Pham, Quoc Trung, Xuan Phuc Tran, Sanjay Misra, Rytis Maskeliūnas, and Robertas Damaševičius. "Relationship between convenience, perceived value, and repurchase intention in online shopping in Vietnam." Sustainability 10, no. 1 (2018): 156.

[38] Park, Mi-ra, and Yen-yoo You. "The Influence of Consumer's Practical Value on Overseas Direct Purchase Intention." Ilkogretim Online 20, no. 3 (2021).

[39] Prasetyo, Yogi Tri, Hans Tanto, Martinus Mariyanto, Christopher Hanjaya, Michael Nayat Young, Satria Fadil Persada, Bobby Ardiansyah Miraja, and Anak Agung Ngurah Perwira Redi. "Factors affecting customer satisfaction and loyalty in online food delivery service during the covid-19 pandemic: Its relation with open innovation." Journal of Open Innovation: Technology, Market, and Complexity 7, no. 1 (2021): 76.

[40] Kang, Peng, Guanghan Song, Ming Xu, Travis R. Miller, Haikun Wang, Hui Zhang, Gang Liu et al. "Low-carbon pathways for the booming express delivery sector in China." Nature Communications 12, no. 1 (2021): 1-8.
[41] Muharam, Hari, Harmon Chaniago, Endraria Endraria, and Amran Bin Harun. "E-Service Quality, Customer Trust and Satisfaction: Market Place Consumer Loyalty Analysis." Jurnal Minds: Manajemen Ide dan Inspirasi 8, no. 2 (2021): 237-254.

[42] Goutam, Doddahulugappa, B. V. Gopalakrishna, and Shirshendu Ganguli. "Determinants of customer satisfaction and loyalty in e-commerce settings: an emerging economy perspective." International Journal of Internet Marketing and Advertising 15, no. 3 (2021): 327-348.

[43] Ziaullah, Muhammad, Yi Feng, and Shumaila Naz Akhter. "E-Loyalty: The influence of product quality and delivery services on e-trust and e-satisfaction in China." International Journal of Advancements in Research \& Technology 3, no. 10 (2014): 20-31.

[44] Marino, Gaetano, Giulio Zotteri, and Francesca Montagna. "Consumer sensitivity to delivery lead time: a furniture retail case." International Journal of Physical Distribution \& Logistics Management (2018).

[45] Chan, Tat, Zekun Liu, and Weiqing Zhang. "Delivery service, customer satisfaction and repurchase: Evidence from an online retail platform." Customer Satisfaction and Repurchase: Evidence from an Online Retail Platform (September 15, 2018) (2018).

[46] Juliantari, Luh Made Putri, Putu Ngurah Suyatna Yasa, and Ni Luh Putu Indiani. "The effect of green marketing and consumers' attitudes on brand image and consumers' purchase intention of green products in Denpasar." Jurnal Ekonomi \& Bisnis JAGADITHA 6, no. 1 (2019): 8-14.

[47] Diallo, Mbaye Fall, and Christine LambeyChecchin. "Consumers' perceptions of retail business ethics and loyalty to the retailer: The moderating role of social discount practices." Journal of business ethics 141, no. 3 (2017): 435-449.

[48] Essamri, Azzouz, Sally McKechnie, and Heidi Winklhofer. "Co-creating corporate brand identity with online brand communities: A managerial perspective." Journal of Business Research 96 (2019): 366-375.

[49] De Mooij, Marieke. Global marketing and advertising: Understanding cultural paradoxes. Sage, 2021.

[50] Sharma, Gunjan, Naval Bajpai, Kushagra Kulshreshtha, Vikas Tripathi, and Prince Dubey. "Foresight for online shopping 
behavior: a study of attribution for "what next syndrome"." foresight (2019).

[51] Davis, Fred D. "Perceived usefulness, perceived ease of use, and user acceptance of information technology." MIS quarterly(1989): 319-340.

[52] Prakosa, Adhi, and Ahsan Sumantika. "An Analysis of Online Shoppers' Acceptance and Trust toward Electronic Marketplace using TAM Model." In Journal of Physics: Conference Series, vol. 1823, no. 1, p. 012008. IOP Publishing, 2021.

[53] Rahman, M. M., \& Sloan, T. (2017). User adoption of mobile commerce in Bangladesh: Integrating perceived risk, perceived cost and personal awareness with TAM. The International Technology Management Review, 6(3), 103-124.

[54] Rattanaburi, Konrawan, And Rawin Vongurai. "Factors influencing actual usage of mobile shopping applications: Generation $\mathrm{Y}$ in Thailand." The Journal of Asian Finance, Economics, and Business 8, no. 1 (2021): 901913.

[55] Limsarun, Tanakorn, Ampol Navavongsathian, Busaya Vongchavalitkul, and Nantaporn Damrongpong. "Factors Affecting Consumer's Loyalty in Food Delivery Application Service in Thailand." The Journal of Asian Finance, Economics, and Business 8, no. 2 (2021): 10251032.

[56] Götz, Friedrich M., Stefan Stieger, Samuel D. Gosling, Jeff Potter, and Peter J. Rentfrow. "Physical topography is associated with human personality." Nature human behaviour4, no. 11 (2020): 1135-1144.

[57] Hair, Joseph F., Christian M. Ringle, and Marko Sarstedt. "Partial least squares: the better approach to structural equation modeling?." Long Range Planning 45, no. 5-6 (2012): 312-319.

[58] Chin, Wynne W. "The partial least squares approach to structural equation modeling." Modern methods for business research 295, no. 2 (1998): 295-336.

[59] Fornell, Claes, and David F. Larcker. "Structural equation models with unobservable variables and measurement error: Algebra and statistics." (1981): 382-388.

[60] Bauerová, Radka, and Martin Klepek. "Technology acceptance as a determinant of online grocery shopping adoption." Acta Universitatis Agriculturae et Silviculturae Mendelianae Brunensis 66, no. 3 (2018): 737746.
[61] Casaló, Luis V., Carlos Flavián, and Miguel Guinalíu. "The role of satisfaction and website usability in developing customer loyalty and positive word- of- mouth in the e- banking services." International journal of bank marketing (2008).

[62] Strzelecki, Artur, and Mariia Rizun. "Consumers' security and trust for online shopping after GDPR: examples from Poland and Ukraine." Digital Policy, Regulation and Governance(2020).

[63] Fadhillah, Auliya, Yuniman Zebua, and Yudi Prayoga. "Analysis of Information Quality, Trust and Satisfaction on Customer Participation (Case Study on Customer Online Shop Shopee in Rantauprapat)." Budapest International Research and Critics InstituteJournal (BIRCI-Journal) Vol 4, no. 2 (2021): 3039-3051.

\section{Creative Commons Attribution License 4.0 (Attribution 4.0 International, CC BY 4.0)}

This article is published under the terms of the Creative Commons Attribution License 4.0 https://creativecommons.org/licenses/by/4.0/deed.e n US 